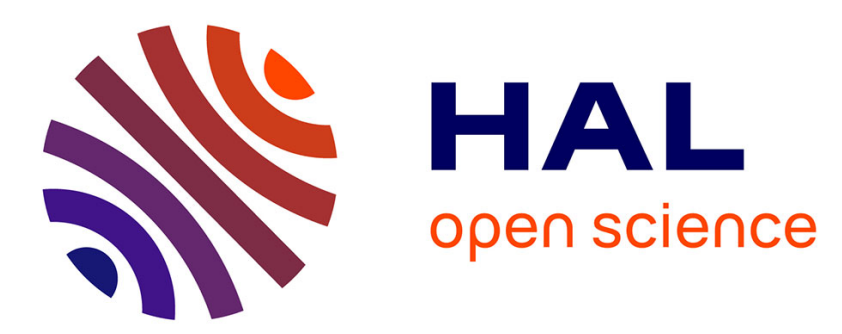

\title{
Market Identification to Generation: A Practice Theory Market Orientation
}

Matthew Hawkins

\section{To cite this version:}

Matthew Hawkins. Market Identification to Generation: A Practice Theory Market Orientation. Journal of Strategic Marketing, 2015, 23 (2), pp.112-121. 10.1080/0965254X.2014.914070 . hal01507884

\section{HAL Id: hal-01507884 \\ https://hal.science/hal-01507884}

Submitted on 13 Jun 2018

HAL is a multi-disciplinary open access archive for the deposit and dissemination of scientific research documents, whether they are published or not. The documents may come from teaching and research institutions in France or abroad, or from public or private research centers.
L'archive ouverte pluridisciplinaire HAL, est destinée au dépôt et à la diffusion de documents scientifiques de niveau recherche, publiés ou non, émanant des établissements d'enseignement et de recherche français ou étrangers, des laboratoires publics ou privés. 


\title{
Market identification to generation: a practice theory market orientation
}

\author{
Matthew A. Hawkins \\ Department of Marketing Management, Ramon Llull University, ESADE Business School, \\ Barcelona, Spain \\ (Received February 19, 2014)
}

\section{Corresponding author information}

Matthew A. Hawkins

ESADE Business School, Ramon Llull University

Aviguda de la Torre Blanca, 59

08172, Sant Cugat del Valles, Spain

Phone: (34) 93.554.35.11

Fax: (34) 93.204.81.05

Email: Matthewallen.hawkins@esade.edu

\begin{abstract}
Author biography
Matthew A. Hawkins is a doctoral candidate at ESADE Business School, Ramon Llull University. Mr. Hawkins focuses on branding and consumption theory with particular attention directed towards object use. He has taught in both the United States of America and Europe as well as being published in the Journal of Organizational Change Management and Management Decisions.
\end{abstract}

\section{Word count}

4,753

\section{Disclosure statement}

The author received no outside funding for this research and has no financial interest nor expectations of any benefit from the direct application of this research. 


\section{Market identification to generation: a practice theory market orientation}

This article puts forth a market perspective based on social practice theory that addresses how marketers and brand managers can view the market, design their marketing mix and market scripting activities and encourage the integration of their offerings into individuals' practices. The main features of this perspective are: only when the brand is resourced is the actual market constituted; a brand is resourced across numerous practices of each user; and, firms have the ability to create new practices. The analysis conceptually develops four market orientations: resource identifier, resource activator, resource configurer and resource generator. These orientations allow for firms to insert their offering into existing practices, reconfigure the way the practice is enacted, or create new practices for their branded resource. It is suggested that brands utilized across multiple practices will have higher repurchasing rates and levels of brand loyalty compared to brands that are not enrolled across multiple practices.

Keywords: practice theory; marketing; branding; market orientation; narrative 


\section{Market identification to generation: a practice theory market orientation}

\section{Introduction}

The new millennium has ushered in an era of connectedness. Understandings of human behavior are shifting from being completely based on biological explanations to those that embrace a socially constituted, networked view of society (Bruner, 1990). Meaning is not an objective fact rather meaning and society are constituted through engaging in practice, observing, interpreting and doing (Giddens, 1984). Therefore society is continuously socially constituted (Searle, 1995). Accordingly, the meaning of discourse, a human movement, an object and even a brand rests on how it is used to fulfill a purpose.

An individual's practice narrative provides the conscious and unconscious rationales that motivate and guide the way they enactment the practice (Hawkins \& Saleem, 2012). However, repeated and regularly enacted practices produce structures, norms and memory traces on how to enact specific practices across individuals (Giddens, 1984; Schatzki, 2006; Sewell, 1992).

Marketers are now being urged to recognize that the meaning of their brand is based on how it is actually used and not how they desire the offering to be used. The rise of co-creation branding (i.e., Payne, Storbacka, \& Frow, 2008), for instance, recognizes that consumer interaction and brand use create meaning and value. Consumer Culture Theory (CCT) similarly embraces the notion that dynamic relationships exist among resources, consumers and brand meaning (Arnould \& Thompson, 2005, 2007). Despite advancements in brand meaning theory, the role of practice in market constitution has yet to be incorporated into a multi-perspective market orientation. Because the consumer has a significant impact on brand meaning researchers have been focused on improving a firm's market reading and learning capabilities (Cayla \& Arnould, 2013; Neill, McKee, \& Rose, 2007; Sinkula, 1994). However, market orientation approaches typically focus on learning about existing consumer practices and not generating new consumer practices. Conversely, design-driven innovation research is concerned with radical innovation that changes the way consumers think and act and less concerned with inserting products into existing practices (Verganti, 2009).

Building on Storbacka and Nenonen's (2011a, 2011b) view of markets as dynamic, evolving resource configuration systems, the purpose of this article is to formalize a resourcemarket orientation based on practice theory principles. This perspective argues firms provide resources for other consumers to enroll into their socially situated practices; and, recognizes that 
a firm's market scripting activities can affect users' practices and routines. Under the resourcemarket perspective there are four main market orientation models: resource identifier, resource activator, resource configurer and resource generator. The main features of this perspective are: only when the brand is resourced is the actual market constituted; a brand is resourced across numerous practices of each user or network member; and, firms have the ability to create new practices and routines.

The following section explains the practice-based theory of resourcing as it provides the foundation for the resource-market perspective. Then, the four practice theory derived market orientations are conceptually developed.

\section{Theoretical foundation: practice-based theory of resourcing}

To develop the resource-market perspective, practice-based theory of resourcing is consulted to explain how a brand or resource enables individuals to enact practices. Practice refers to the act of enrolling resources to accomplish a goal in a specific time and space (Jarzabkowski, Lê, \& Feldman, 2012; Levina \& Orlikowski, 2009). Practice theory argues that the meaning of discourse, actions, and objects are (re)constituted through doing. Therefore, social reality is not stable but continuously (re)constituted. Accordingly, to understand the meaning of any resource it cannot be isolated and abstracted from its usage context (Brown \& Duguid, 1991; Lave, 1996; Lave \& Wenger, 1991). Polanyi (1962) echoes the importance of context by arguing that interpreting objects, actions and discourse "are intelligible only within the framework of a useful performance which they successfully serve" (p. 185). Therefore, practice theory provides a strong theoretical foundation for contemporary market approaches by recognizing that the resource system the offering is integrated into determines its meaning (Hatch \& Schultz, 2010; Payne, Storbacka, Frow, \& Knox, 2009) and by embracing the idea that resource systems can exhibit relative stability allowing for market identification.

Resources are considered to be any object, action, or discourse that an agent expects to assist them in enacting a practice (Feldman, 2004; Feldman \& Worline, 2011; Sewell, 1992). As a resource, individuals rely on their narratives or schemas when deciding to resource a brand into a practice. Narratives are an individuals sensemaking cognitive framework that gives meaning to objects, brands and practices (Hawkins \& Saleem, 2012). 
It is helpful to distinguish between abstracted and contextualized brand meanings as there is a significant body of literature that relies on brand perceptions abstracted from context. Accordingly, brand-as-artifact refers to brand perceptions that are decontextualized and are not socially situated (Orlikowski, 2000). It is through repeated, structuralized interactions that produce similar results that viewing brands and markets as stable artifacts makes sense. Conversely, brand-in-practice refers to brand meanings stemming from the brand being resourced in a particular context (Orlikowski, 2000). Methodologically, surveys that assess brand meaning using contextually devoid indicators (e.g., brand personality (Aaker, 1997)) investigate brand-as-artifact meanings while ethnographic and cultural studies are better positioned to capture brand-in-practice meanings.

\section{Resourcing corollary}

As brands are only considered a resource when in-practice, the resourcing corollary to practice theory explains how brands are enrolled into practices. Under the resourcing corollary, a resource is created when it is enrolled into a practice, before integration it was only a potential resource (Feldman \& Orlikowski, 2011; Feldman \& Worline, 2011). In relation to branding, a brand is not defined by its innate qualities but by how the brand is (not) used to accomplish a goal in-situ. Accordingly, marketers attempt to have their offering viewed as a potential resource for practice enactment. The value placed on practice then brings the dynamic nature of brand meaning to the fore. An individual's reality is structured through repeated actions resulting in a structured resource system that can lead to relatively stable in-practice meanings (Giddens, 1984). However, using brands-as-artifact methods to assess brand meanings fail to recognize the contextually-based nature of brand-in-practice meanings and can result in overlooking market changes. Accordingly, marketing perspectives that internalize practice's role in (re)constituting resources are better suited to not only develop a more refined understanding of a particular brand's meaning but, as to be argued, they can also facilitate generating new practices and markets that resource the brand.

\section{Resource-market perspective}

A forward-looking managerial perspective of the market should account for traditional marketing orientations that focus on identifying markets as well as contemporary orientations that strive to 
create new cultural meanings, practices and markets. As Storbacka and Nenonen (2011a, 2011b) argue, markets that exhibit relative stability can be said to have high marketness. At the other end of the continuum, markets exhibiting low marketness are resource systems still being contested. Accordingly, approaches to the market should explicitly recognize the degree of marketness of the system they are contributing to.

The four market orientations under a resource-market perspective are: 1) resource identifier (RI), 2) resource activator (RA), 3) resource configurer (RC), and; 4) resource generator (RG) (see Table 1). Multiple views of marketing activities are necessary to capture the dynamism of the market, since as soon as other firms begin to target new practices promoted under a market generating approach their marketing orientations are either identifying, activating or configuring.

Insert Table 1 about here

\section{Resource identifier}

The first resource-market approach is the resource identifier and is a commonly advocated branding strategy. As McCracken (1986) and Escalas and Bettman (2005) argue, this is where culturally relevant attributes are embedded into goods and brands through advertising and opinion leaders. In particular, RI strategies attempt to identify and insert their brand into the socially constituted world in a manner that allows it to be seen as a resource to enroll into identifiable, previously enacted practices. An RI strategy requires a mature market with high marketness that has at least one practice repeatedly enacted by a relatively large number of actors to target.

As practices are repeated through time and space, the resource system exhibits stability thereby increasing the attractiveness and applicability of the RI orientation. A brand can obtain strong market differentiation by owning or associating with relevant resource(s). Implementing brand-as-artifact research methods, such as surveys can be useful under RI. This research can then be used to identify and assess brand attributes to develop market differentiation strategies. 
The strategic challenges, besides marketing mix development and implementation, are resisting organizational inertia and believing the market is stable (Hannan \& Freeman, 1977, 1984).

\section{Resource activator}

Market strategies that pursue differentiation within the practice's dominate resource configuration but provide branded resources outside actors' current decision making sets are approaching the market under a resource activator (RA) orientation. This strategy is particularly attractive for new market entrants or firms with limited resources who want to avoid directly competing with brand(s) that own market attributes by juxtaposing their brand against dominant discourses or stories presented by market leaders. But, as the activated market grows in size it becomes easier and more attractive for other firms to identify. Firms with multiple product lines could experiment with the RA market approach to grow market share or decrease costs through economies of scale.

The challenge presenting managers under an RA orientation is correctly reading culture to avoid promoting a branded resource that is too far from the dominate practice narrative. Adjusting the way actors configure resources requires clout (Storbacka \& Nenonen, 2011a, 2011b) and the more novel the promoted configuration the more challenging it will be to adjust users' narratives and practices. Research methods that not only gauge where culture is but where culture is going are vital in this orientation. Projective research methods that ask respondents to visualize their behavior in particular situations can be helpful. Work on consumption collectives highlight that understanding brand-in-practice meanings offers various benefits to firms (McAlexander, Schouten, \& Koenig, 2002) including identifying future trends (von Hippel, 2005). Therefore, qualitative and cultural research on consumption collectives can help guide market scripting activities.

\section{Resource configurer}

Rather than working within a practice's dominant resource configuration narrative, a resource configurer (RC) orientation promotes alternative practice resource configuration narrative when approaching the market. Marketers then attempt to strategically embed these attributes into their brand in hopes of being viewed as a potential resource. This allows dynamic firms to overtake 
competing firms suffering from organizational inertia and less likely to adjust marketing strategies to meet the newly configured market.

Constructing and promoting novel resource configurations involve considerable risk and uncertainty. Users can be reluctant to view their practice in the way promoted by the firm's marketing mix. As Feldman (2004) shows the resulting change in the constitution of one practice will change how resources in other practices are viewed. A resource can be, and is often, resourced across numerous overlapping practices; the ripple effect from a resource change in one practice could change more important practices thereby preventing (or promoting) brand adoption. Thus, brands that are resourced across multiple practices can be challenging to replace.

The resource configurer market orientations can be viewed as precursors to the RI and RA models. This is because only one firm can promote a new practice; other marketers are then working within the newly promoted resource configuration narrative. Conducting contextually rich research enables managers to strategically develop marketing mixes based on new resourcing stories that are unique, attractive, and easy for actors to integrate into their practice narrative. Qualitative research, such as interviews and focus groups are relatively inexpensive ways to learn brand-in-practice meanings. However, observation- and participant-based research methods allow for social and tacit knowledge to be gathered.

\section{Resource generator}

Resource generator (RG) strategies focus on developing and promoting new practices and providing the necessary resource(s) for enacting the practice. RG orientations embrace the firm's ability to co-construct new practices through the promotion of new narratives. Similarly, agency enables individuals to overcome the suggestive power of structures to create new ways of performing (Reckwitz, 2002). The constitution of new practices and markets relying upon branded objects offer strategists the opportunity to tightly intertwine their offered resource(s) into the practice narrative. This is similar to studying lead-users since they may be generating new practices or re-configuring existing practices using resources that could be produced by a firm (von Hippel, 1986). As the practice is (re)invented (Shove \& Pantzar, 2005) through time additional practices can become interwoven into this new practice potentially allowing the brand to become a core resource across multiple practices or within a performance. This point further 
supports the notion that brands enrolled across multiple practices are difficult to replace and can elevate brand loyalty and repurchasing rates.

Creating a practice that is replicable at a collective level and across time and contexts is a challenging endeavor. The practice needs to be accepted by others and this involves considerable organizational learning that demands firm investments of thought, time, and money into supporting the new practice during a period of low marketness. Verganti (2009) discusses the extraordinary efforts Italian design firms go through to promote their design-driven innovations. Designers spend years conducting cultural research (archival and ethnographic) to understand where culture is going. Then, they expend considerable resources (time, money) to promote their new view, such as targeting opinion leaders and trend setters (Verganti, 2009). Furthermore, market players who delay entrance can benefit from learning; both learning from the failures of the market generator and from consumers learning how to use the product that might increase future acceptance. Overall, holistic research (Patton, 2002) strategies should be executed in order to develop a contextually rich understanding of where culture is going. This includes participantbased research, as gaining legitimacy within a consumption collective can be leveraged to encourage practice adoption and brand use (Canniford, 2011).

\section{Discussion}

The resource-market perspective has three main features. First, while marketers desire to identify or generate the meanings and markets they would like to work within, it is only when the brand is resourced is the actual market constituted. Taking a brand-as-artifact approach or developing a brand image solely through surveys do not provide significant insight into in-use meaning which stems from how a brand is actually integrated into practices.

Second, stories and narratives from all relevant stakeholders should be gathered to assess in-use meaning across all supply chain members (Storbacka \& Nenonen, 2011a). Creating a clear picture of brand-in-practice meanings needs to include the views of all supply chain members, which the resource-market perspective lends itself to. Therefore, collecting and analyzing the stories from buyers, regulators, stockholders, employees and other major brand network members will provide a more complete view of a brand's-in-practice meanings than just focusing on end-users, for instance. 
Third, generating a new practice and market are difficult and other companies can start promoting marketing mixes under RI, RA or RC orientations to position themselves within the emerging market. Accordingly, firms need a certain level of market power or clout to continue to influence market configurations, especially within low marketness contexts. The promotion of resourcing stories: expressed frameworks on how practice should enroll a particular brand can help with marketing scripting. A resourcing story has a different objective than developing a unified core brand value in stakeholders (de Chernatony and Harris, 2000; de Chernatony and Riley, 1998) through storytelling. Core brand values are static attributes incorporated into stakeholders' knowledge set, such as viewing the brand as trust-worthy or innovative. I argue managers should strive to develop a shared narrative that includes what the brand does and how the brand should be resourced into practices. This would addresses how the brand fits into a larger assemblage of resources in a continuously transitioning social system and is not a value or singular attribute. Brands needs to be seen as a resources that does something - not is something - in overlapping systems of practices and performances.

\section{Theoretical contributions}

Theoretically, the conclusion that a brand can serves as a core resource offers a novel explanation for increased brand loyalty. As repeated actions structuralize the environment (Giddens, 1984), brands that can integrate themselves into multiple practices should be better able to survive in competitive markets than brands that are not. And, brand value increases as the in-practice knowledge becomes utilizable across multiple practices and routines (Boisot, 1998). This suggests that brands utilized across multiple practices will have higher repurchasing rates and levels of brand loyalty compared to brands that are not enrolled across multiple practices.

\section{Managerial recommendations}

The four market orientations of the resource-market perspective are particularly valuable for strategists and marketing managers. Brands that are repeatedly enrolled in practices and enjoy relatively high marketness need to be aware that the market is not stable. Therefore, by analyzing competing brands firms can offer guidance on how to strategically (re)position a brand so that it continues to maintain a strong presence within a dense but always adjusting collection of individual practices. While, new market entrants can analyze practice narratives to develop 
marketing mixes that avoid direct confrontation with market leaders. Accordingly, brand-asartifact meanings tend to be more valuable to brands operating with RI and RA orientations while brands pursuing RC and RG strategies value brand-in-practice meanings. It is recommended that firms select positioning strategies based upon market research capabilities. Firms that are still developing interpretive research competencies should consider RI and RA strategies. Conversely, firms with active ethnographic research departments could consider pursuing RC or RG strategies. Conducting field research has an additional benefit of providing firms with an opportunity to legitimately, but peripherally participate in relevant consumption collectives (Brown \& Duguid, 2001; Lave \& Wenger, 1991). Once community legitimacy is earned, the firm can exert influence in guiding shared interests and practices towards areas the firm can exploit to generate revenue or to shield the community from branded resources offered by competing firms.

The ability of a brand to serve as a resource across multiple practices is an important concept to internalize. Understanding that brands are resourced to support the enactment of multiple, overlapping practices can help managers implement changes that minimize impacts across practices thereby improving adoption rates (Feldman, 2004). This finding deserves further attention as Storbacka and Nenonen (2011a, 2011b) argue competitive advantages stem from non-redundant network relationships while the resource-market perspective suggests that redundant relationships among resources not only creates the market but also offers the opportunity to firmly and deeply embed offerings into a brand users' practices.

\section{Conclusion}

The resource-market perspective builds upon Storbacka and Nenonen's (2011a, 2011b) view of markets as dynamic and evolving resource configuration systems to offer managers and researchers a framework to view brand meaning and to develop marketing mixes that explicitly embraces the prominent role of the usage context in market formation (Vargo \& Lusch, 2011). It is argued that despite the socially constituted nature of markets, the structuralization provided by repeated, collective action leads to relative market stability. This stability allows marketers and entrepreneurs to identify markets. However, firms are able to configure new ways to view the market or to generate new markets through the promotion of new practices and routines. 


\section{Acknowledgements}

The author would like to thank Polina Landgraf, Russ Nelson, Tanusree Jain and Núria Nadal for their thoughtful feedback during the development and writing processes. Additionally, a version of this paper was presented at the $3^{\text {rd }}$ Annual GIKA Conference and received valuable feedback from the participants. Portions of this paper were written while visiting the University of Arkansas-Fayetteville

\section{References}

Aaker, J. L. (1997). Dimensions of brand personality. Journal of Marketing Research, 34(3), 347-356.

Arnould, E. J. \& Thompson, C. J. (2005). Consumer culture theory (CCT): Twenty years of research. Journal of Consumer Research, 31(4), 868-882.

Arnould, E. J. \& Thompson, C. J. (2007). Consumer culture theory (and we really mean theoretics): Dilemmas and opportunities posed by an academic branding strategy, In: R. W. Belk \& J. F. Sherry (Eds). Consumer culture theory, Vol. 11 of research in consumer behavior (pp. 3-22). Boston, MA: Elsevier.

Boisot, M. H. (1998). Knowledge assets: Securing competitive advantage in the information economy. Oxford: Oxford University Press.

Brown, J. S. \& Duguid, P. (1991). Organizational learning and communities-of-practice: Toward a unified view of working, learning, and innovation. Organization Science, 2(1), 40-57.

Brown, J. S. and Duguid, P. (2001). Knowledge and organization: A social-practice perspective. Organization Science, 12(2), 198-213.

Bruner J. (1990). Acts of meaning. Cambridge, MA: Harvard University Press.

Canniford, R. (2011). How to manage consumer tribes. Journal of Strategic Marketing, 19(7), 591-606.

Cayla, J. \& Arnould, E. J. (2013). Ethnographic stories for market learning. Journal of Marketing, 77(4), 1-16.

de Chernatony, L. \& Harris, F. (2000). Developing corporate brands through considering internal and external stakeholders. Corporate Reputation Review, 3(3), 268-274. 
de Chernatony, L. \& Riley, F. D. O. (1998). Modelling the components of the brand. European Journal of Marketing, 32(11/12), 1074-1090.

Escalas, J. E. \& Bettman, J. R. (2005). Self-construal, reference groups, and brand meaning. Journal of Consumer Research, 32(3), 378-389.

Feldman, M. S. (2004). Resources in emerging structures and processes of change, Organization Science, 15(3), 295-309.

Feldman, M. S. \& Orlikowski, W. J. (2011). Theorizing practice and practicing theory, Organization Science, 22(5), 1240-1253.

Feldman, M. S. \& Worline, M. (2011). Resources, resourcing, and ampliative cycles in organizations, In K. S. Cameron \& G. Spreitzer (Eds.), Oxford handbook of positive organizational scholarship,(pp. 629-641). New York, NY: Oxford University Press.

Flory, M. \& Iglesias, O. (2010). Once upon a time. Journal of Organizational Change Management, 23(2), 113-119.

Giddens, A. (1984). The constitution of society: Outline of the theory of structuration. Los Angeles, CA: University of California Press.

Hannan, M. T. \& Freeman, J. (1977). The population ecology of organizations. American Journal of Sociology, 82(5), 929-964.

Hannan, M. T. \& Freeman, J. (1984). Structural inertia and organizational change. American Sociological Review, 49(2), 149-164.

Hatch, M. J. \& Schultz, M. (2010). Toward a theory of brand co-creation with implications for brand governance. Journal of Brand Management, 17(8), 590-604.

Hawkins, M. A. \& Saleem, F. Z. (2012). The omnipresent personal narrative: Story formulation and the interplay among narratives. Journal of Organizational Change Management, 25(2), 204-219.

Jarzabkowski, P. A., Lê, J. K., \& Feldman, M. S. (2012). Toward a theory of coordinating: Creating coordinating mechanisms in practice. Organization Science, 23(4), 907-927.

Lave, J. (1996). The practice of learning. In S. Chaiklin \& J. Lave (Eds.), Understanding practice: Perspectives on activity and context (pp. 27-44). Cambridge, UK: Cambridge University Press.

Lave, J. \& Wenger, E. (1991). Situated learning: Legitimate peripheral participation. Cambridge, UK: Cambridge University Press. 
Levina, N. \& Orlikowski, W. J. (2009). Understanding shifting power relations within and across organizations: A critical genre analysis. Academy of Management Journal, 52(4), 672-703.

McAlexander, J. H., Schouten, J.W., \& Koenig, H. F. (2002). Building brand community. The Journal of Marketing, 66(1), 38-54.

McCracken, G. (1986). Culture and consumption: A theoretical account of the structure and movement of the cultural meaning of consumer goods. Journal of Consumer Research,13(June), 71-84.

Neill, S., McKee, D., \& Rose, G. M. (2007). Developing the organization's sensemaking capability: Precursor to an adaptive strategic marketing response. Industrial Marketing Management, 36(6), 731-744.

Orlikowski, W. J. (2000). Using technology and constituting structures: A practice lens for studying technology in organizations. Organization Science, 11(4), 404-428.

Patton, M. Q. (2002). Qualitative research \& evaluation methods. Thousand Oaks, CA: Sage Publications.

Payne, A., Storbacka, K., \& Frow, P. (2008). Managing the co-creation of value. Journal of the Academy of Marketing Science, 36(1),83-96.

Payne, A., Storbacka, K., Frow, P., \& Knox, S. (2009). Co-creating brands: diagnosing and designing the relationship experience. Journal of Business Research, 62(3), 379-389.

Polanyi, M. (1962). Personal knowledge: Towards a post-critical philosophy (2005 e-book ed.), London, UK: Taylor \& Francis Group e-Library.

Reckwitz, A. (2002). Toward a theory of social practices: A development in culturalist theorizing. European Journal of Social Theory, 5(2), 245-265.

Schatzki, T. R. (2006). On organizations as they happen. Organization Studies, 27(12), 18631873.

Searle, J. R. (1995). Construction of social reality. New York, NY: Free Press.

Sewell, Jr., W. H. (1992). A theory of structure: Duality, agency, and transformation. American Journal of Sociology, 98(1), 1-29.

Shove, E. \& Pantzar, M. (2005). Consumers, producers and practices: Understanding the invention and reinvention of Nordic walking. Journal of Consumer Culture, 5(1), 43-64.

Sinkula, J. M. (1994). Market information processing and organizational learning. The Journal of Marketing, 58(1), 35-45. 
Storbacka, K. \& Nenonen, S. (2011a). Markets as configurations. European Journal of Marketing, 45(1/2), 241-258.

Storbacka, K. \& Nenonen, S. (2011b). Scripting markets: From value propositions to market propositions. Industrial Marketing Management, 40(2), 255-266.

Vargo, S. L. \& Lusch, R. F. (2004). Evolving to a new dominant logic for marketing. Journal of Marketing, 68(1), 1-17.

Vargo, S. L. \& Lusch, R. F. (2011). It's all B2B... and beyond: Toward a systems perspective of the market. Industrial Marketing Management, 40(2), 181-187.

Verganti, R. (2009). Design driven innovation: Changing the rules of competition by radically innovating what things mean. Boston, MA: Harvard Business Press.

von Hippel, E. (1986). Lead users: A source of novel product concepts. Management Science, 32(7), 791-805.

von Hippel, E. (2005), Democratizing innovation, Cambridge, MA: The MIT Press. 


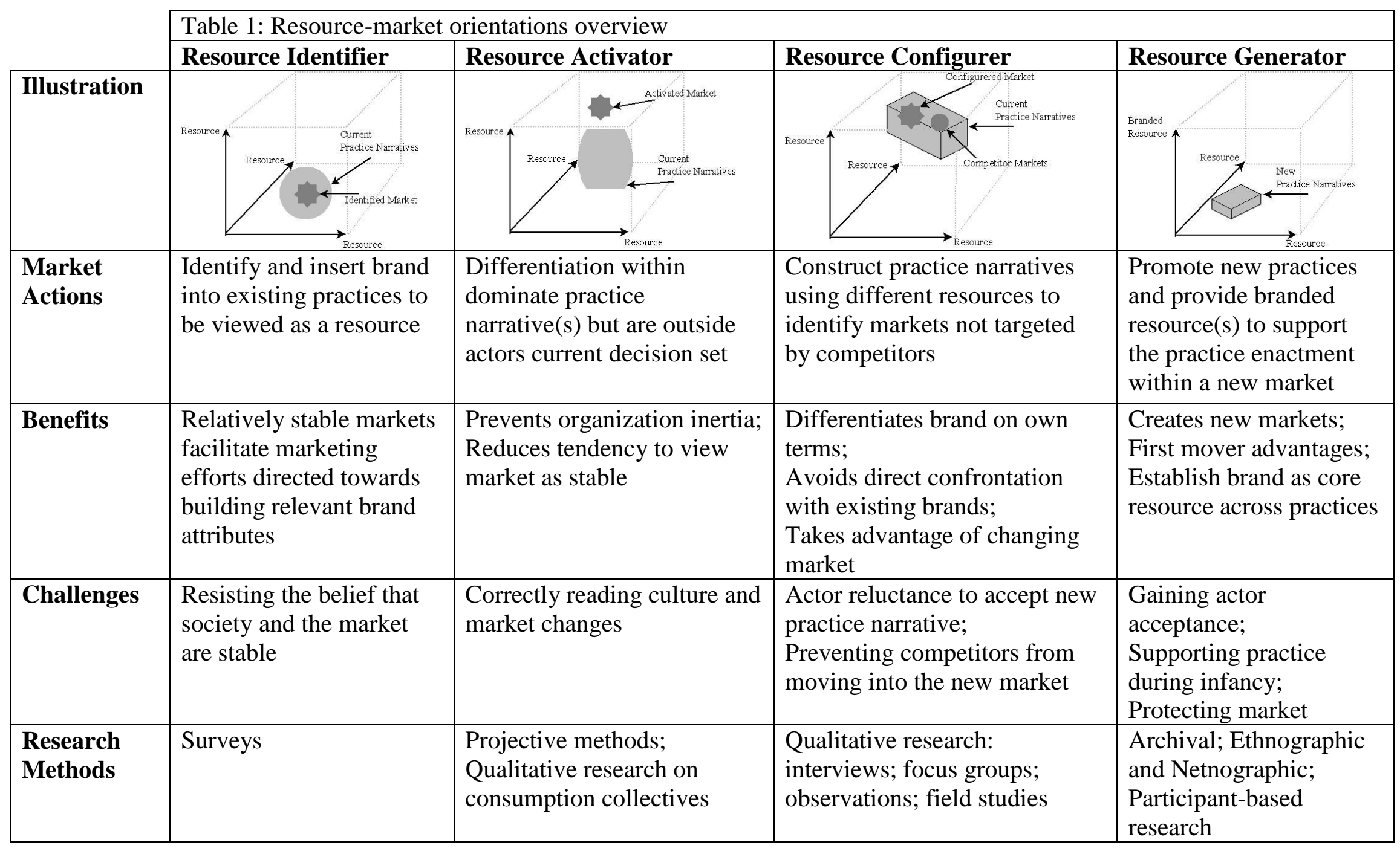

